\title{
Mengkaji Relasi Agama dan Ideologi
}

\section{Roni Dwi Hartanto}

Sekretaris Eksekutif di Center For Nationalism Studies (CNS).

email: ronidwihartantol98/@gmail.com

\begin{abstract}
Religion and ideology are two interesting terms to be discussed and researched. Both of the terms were able to give an ideal purpose of life which is desirable by every human being. Both of religion and ideology were able to give comprehensive description about the "ideal-things" which is intended by the human being to look for the happiness of life. Both of religion and ideology have properly arranged the way to achieve the "ideal-condition" even needed serious struggle to realize it. Moreover, both of religion and ideology have also given inner satisfaction and strength to their followers.

Religion and ideology can be illustrated as 'both side of coin' which is interrelated. Ideology can be as religion because of its power which is able to make available of the "ideal way" (solution) for its followers. As well as ideology, religion is not just spiritual way, but also able to make available "ideal description" and straighten up the dimension of life, socially, politically, and also culturally.
\end{abstract}

\section{Keywords}

Religion, Ideology, Relation of Ideology and Religion, Modernity, and genocide.

\section{Pendahuluan}

Modernitas yang diharapkan mampu menjawab persoalan manusia, kini justru melahirkan paradoks. Modernitas telah membawa manusia pada perang, krisis rasionalitas, identitas maupun budaya. Revolusi industri dan ditemukannya alat-alat modern justru mengakibatkan manusia teralienasi pada jejaring semu rasionalitas dan hasil ciptaannya sendiri. Meminjam 
istilah Jean baudrillard, manusia kini hidup dalam galaksi simulacra, dimana yang asli dan tiruan tidak dapat dibedakan lagi akibat perkembangan ilmu pengetahuan dan teknologi. Di abad ini, senjata-senjata pemusnah massalpun diciptakan untuk menghadapi teror dan perang. Akibatnya, jutaan manusia tak berdosa mati terbunuh (Barker 2009, 118; Sugiharto 1996, 29).

Drama yang sungguh menyedihkan di abad rasionalitas (?) Di abad ini, banyak orang rela mati demi keyakinan yang diyakini kebenarannya, dan pada saat yang bersamaan banyak orang membunuh sesama tanpa merasa berdosa. Dalam catatan sejarah, kita bisa melihat genocide (genocide adalah kejahatan atau konspirasi untuk memusnahkan sekelompok orang atas perbedaan identitas etnis, kebangsaan, ras, atau agama. Pembantaian massal ini telah berlangsung sejak lama. Pada abad 5 pasukan atau angkatan perang Atilla melakukan pembunuhan besar-besaran. Pada abad 13, pasukan Jenghis Khan melakukan pembantaian terhadap orang Timur Tengah) yang dilakukan Hitler, Pinochet, Suharto dan rezim-rezim totaliter lainnya. Jika kita cermati, lebih sering tindakan barbar tersebut dilatarbelakangi oleh perbedaan ideologi maupun agama yang telah dipolitisasi dan dimanipulasi yang lantas berkembang menjadi konflik terbuka yaitu perang.

Kajian Dr. Helen Fein menyebutkan bahwa, ada kaitan yang erat antara genocide dan ideologi. Hasil penelitiannya menunjukkan:

- Pertama, pada Perang Dunia I (1914-1918), pemerintahan Kekaisaran Ustmani mendeportasi dua pertiga warga (lebih dari hampir I juta hingga 1,8 juta) Armenia Anatolia Timur (Turki-Asia sekarang). Kebijakan deportasi ini diikuti oleh tindakan pembantaian dan pemerkosaan yang menyebabkan kelaparan dan dehidrasi.

- Kedua, selama Perang Dunia II terjadi kejahatan kemanusiaan holocaust yang dilakukan tentara NAZI terhadap etnis Yahudi. Genocide yang sangat sistematis itu telah membunuh 5-6 juta orang Yahudi. 
- Ketiga, sejak akhir Perang Dunia II, sedikitnya terdapat 16 rezim penguasa yang melakukan genocide di Negara-negara Afrika, Amerika, Asia, dan Eropa. Di Kamboja (1975- 1979) Komunis Khmer Merah membunuh sekitar 1,7 rakyat kamboja. Perang sipil di Guatemala antara tahun 19601996, diperkirakan 200.000 orang telah terbunuh atau dihilangkan oleh pemerintah militer Guatemala sayap-kanan. Dalam kasus ini, pemerintah militer secara spesifik menjadikan orang-orang asli Maya sebagai target pembunuhannya. Perang suku/etnis Tutsi dengan Hutu di Rwanda tahun 1994 mengorbankan antara 500.000 - 1juta penduduk yang kebanyakan adalah orang-orang Tutsi. Mereka dibunuh pascakudeta kelompok ekstrimis kelompok etnis Hutu. Sejak 1991 ribuan orang, terutama muslim Bosnia menjadi korban genocide dalam peperangan yang terjadi antarnegara Yugoslavia (Encarta Encyclopedia 2003).

Hasil kajian Fein di atas secara tersirat menunjukkan bagaimana relasi agama dan atau ideologi berbanding lurus dengan terjadinya pembantaian massal dalam peradaban manusia. Pada satu sisi, nampaknya agama dan ideologi-lah yang turut memberikan dalil maupun legitimasi terhadap tindakan kekerasan yang selama ini terjadi. Pada sisi yang lain, bisa jadi ideologi dan agama telah dipolitisasi dan dimanipulasi oleh seseorang, kelompok maupun golongan untuk kepentingan pribadi, kelompok, maupun golongannya.

Tulisan ini akan mencoba menguraikan konsep ideologi dan agama secara subtantif. Harapannya, dari penelusuran konsep mengenai ideologi dan agama kita bisa mengetahui akar penyebab konflik yang terjadi, dan memahami apa sebenarnya yang menjadi motif bagi konflik yang hingga kini masih berlangsung. Tulisan ini secara singkat juga akan menguraikan masa depan ideologi dan agama diera globalisasi ini.

\section{Tentang Ideologi}

Ideologi adalah segala rangkaian ide-yang acapkali berwawasan luas bila dipandang secara obyektif, di luar penerapan politisnya (secara 
keliru)-yang tersaji sedemikian rupa sehingga "orang-orang yang percaya" memandang bahwa diri mereka memiliki monopoli atas kebenaran. Ideology adalah sistem pemikiran yang tersusun rapi yang tidak hanya diperlakukan sebagai mitos oleh orang-orang "yang tinggal didalamnya", tetapi juga dipaksakan kepada orang-orang yang tidak mau menerima mitos itu sebagaimana adanya (Palmquis, 2002).

Istilah ideologi sendiri pertama kali dikenalkan oleh Destutt De Tracy. Dia merupakan pemikir Perancis yang memposisikan ideology vis a vis dengan gagasan teologis dan metafisika tradisional. Ideology dalam pengertiannya bersifat positifistik yang tujuannya untuk menemukan kebenaran di luar otoritas agama. Ide-idenya ini terpengaruh oleh gagasan zaman pencerahan terutama Francis Bacon yang mencoba mensterilkan ilmu pengetahuan dari prasangka agama, kepentingan pribadi, dan kepercayaan mistik-metafisik dengan mengukuhkan metode ilmiah sebagai satu-satunya epistemologi yang sahih.

Menurut John Storey (2004) ada lima konsep ideologi. Diantara adalah: pertama, ideologi mengacu pada suatu pelembagaan gagasan secara sistematis yang diartikulasikan oleh sekelompok masyarakat tertentu. Misalnya, ketika kita berbicara ideologi Partai Buruh maka sebenarnya kita sedang membahas tentang ide-ide dasar yang dijadikan sebagai pandangan hidup, ideal-ideal, basis visi, praktek politik, ekonomi, dan sosial partai tersebut.

Kedua, ideologi sebagai usaha penopengan dan penyembunyian realitas tertentu. Ideologi merupakan seperangkat alat untuk memanipulasi kesadaran massa (penulis).

Di sini ideologi digunakan sebagai alat untuk mengungkap bagaimana teks-teks dan praktek budaya tertentu digunakan untuk menghadirkan citra-citra tertentu yang telah diseleksi, direduksi dan didistorsi yang kemudian memproduksi apa yang disebut oleh Mark dan Engels dalam The German Ideology sebagai kesadaran Palsu. 
Ketiga, definisi ideologi yang terkait erat dengan-dan dalam beberapa hal tergantung kepada-definisi kedua, yakni ideologi yang mengejawantahkan dalam bentuk-bentuk ideologis. Dalam hal ini ideologi dimanfaatkan sebagai alat untuk menarik dan memikat perhatian pemirsa terhadap teks-teks yang ditampilkan dalam bentuk fiksi TV, lagu pop, novel, film, roman, dan bentuk hiburan lainnya. Disinilah terjadi apa yang oleh Stuart Hall dalam The Rediscovery of Ideology: the Return of the Repressed in Media Studies (1985) disebut "politik penandaan" sebagai upaya untuk menundukkan para pembacanya melalui cara pandang dunia tertentu.

Keempat, ideologi bukan hanya sebagai pelembagaan, tetapi sekaligus juga sebagai praktek material. Definisi dikemukakan oleh Louis Althusser dalam buku Ideology and Ideological Apparatus. Baginya, ideologi sebenarnya bisa dijumpai dalam praktek kehidupan sehari-hari. Althuser menegaskan aktivitas-aktivitas ritual, upacara, adat, dan kebiasaan tertentu yang lazim kita lakukan dalam kehidupan sehari-hari nyata-nyata memproduksi akibat-akibat yang mengikat dan melekatkan kita pada suatu tatanan sosial yang mapan, sebuah tatanan yang ditandai oleh adanya kesenjangan status dan gap kekuasaan yang menonjol antara yang pusat dan peripheral, yang Maha dan yang hamba.

Kelima, ideologi yang difungsikan pada level konotasi (tersirat), makna sekunder, makna yang seringkali tidak disadari yang terdapat pada teks dan praktek kehidupan. Definisi ini dikemukakan Roland Barthes. Ideologi (atau mitos dalam istilah Barthes) mengarahka kita pada perjuangan hegemonik untuk membatasi makna konotatif, menetapkan konotasi-konotasi particular, dan memproduksi konotasi-konotasi baru. Contoh: sweeping terhadap buku-buku yang dianggap radikal untuk membendung dan mengantisipasi terorisme. Hal serupa juga terjadi terhadap pembredelan buku yang dianggap kiri beberapa tahun yang lalu. Bagi Barthes, inilah yang merupakan contoh klasik ideologi, yakni upaya untuk menjadikan apa yang pada faktanya particular menjadi universal dan 
legitimate, dan juga upaya untuk menaturalkan hal-hal yang pada faktanya kultural.

Bagi Althusser, ideologi adalah satu dari tiga unsur atau level primer formasi sosial. Jadi, ideologi relatif otonom dari level lain (misalnya, ekonomi), meskipun ditempatkan 'pada urutan terakhir'. Di sini, ideologi, 'sistem (dengan logika dan kaidahnya sendiri) representasi (citra, mitos, gagasan atau konsep)' (Althusser: 1969, 231), dipahami sebagai praktik yang dijalani dan mentransformasikan dunia materi. Ada empat aspek dalam karya Althusser yang menjadi inti pandangannya tentang ideologi (Barker 2009, 59):

- Ideologi memiliki fungsi umum untuk membentuk subjek

- Ideologi sebagai pengalaman yang dijalani tidaklah palsu

- Ideologi sebagai pemahaman yang keliru tentang kondisi nyata eksistensi adalah palsu

- Ideologi terlibat dalam reproduksi formasi-formasi sosial dan relasi mereka terhadap kekuasaan.

Ideologi mengatur bagaimana kita hidup berdampingan dengan orang lain dengan nilai tertentu yang kita yakini (particular), dia juga mengatur bagimana masyarakat diatur dan diorganisasikan demi kesejahteraan bersama (universal) tentunya dengan tujuan-tujuan yang ideal demi kemaslahatan umat manusia.

Istilah Ideologi seringkali hanya diartikan sebagai sebuah sistem ide, seperti misalnya ketika orang berbicara tentang ideologi liberal, konservatif atau sosialis. Bagi Gramsci, ideologi lebih dari sekedar sistem ide. Ia membedakan antara sistem yang berubah-ubah (arbitrary systems) yang dikemukakan oleh intelektual dan filosof tertentu, dan ideologi organik yang bersifat historis (bistorically organic ideologies), yaitu ideologi yang diperlukan dalam kondisi sosial tertentu: "Sejauh ideologi itu secara historis diperlukan, ia mempunyai keabsahan yang bersifat psikologis: ideologi 'mengatur' manusia, dan memberikan tempat bagi manusia untuk 
bergerak, mendapatkan kesadaran akan posisi mereka, perjuangan mereka, dan sebagainya" (SPN 367). Ideologi bukanlah fantasi perorangan, namun terjelma dalam cara hidup kolektif masyarakat. Di sini Gramsci merujuk pada pendapat Marx tentang 'soliditas keyakinan masyarakat' (Simon 2000, 83-84).

Secara sederhana ada dua jenis ideologi: Ideologi manusiawi dan ideologi kelas. Ideologi manusiawi adalah ideologi yang didedikasikan untuk seluruh umat manusia, bukan untuk kelas, ras atau masyarakat tertentu saja. Format ideologi seperti ini meliputi seluruh lapisan masyarakat dan tidak hanya lapisan atau kelompok tertentu saja.

\section{Menyimak Agama?}

Agama adalah ajaran yang diturunkan oleh Tuhan untuk dijalankan oleh umat pemeluknya di muka bumi. Adapun tujuannya adalah, supaya manusia dapat mencapai kebahagiaan dunia dan akhirat. Agama juga mengatur bagaimana manusia berhubungan. Yaitu, hubungan dengan sesama dan dengan Tuhannya. Tentu, setiap agama mempunyai ritualitas keagamaan yang berbeda-beda.

Menurut John D. Caputo inti agama adalah cinta kasih, sehingga seorang religius adalah orang yang memiliki cinta kasih. Dengan pengertian ini kategori religius tidak cukup dilihat dari ketaatan ritualistik ataupun dengan pemahaman yang sektarian yang membagi komunitas Yahudi, Islam, Kristen, Hindu dan sebagainya. Kategori religius hanya relevan dilawankan dengan egois, individualis, serakah, dan tidak memiliki cinta kasih. Maka, bisa jadi seorang ateis yang memiliki nilai cinta antar sesamanya lebih religius dari umat beragama.

Mengenai batasan Sofyan H. Abdullah mengatakan: "Agama yang diturunkan oleh Allah" membatasi agama yang disifatkan sebagai agama yang tidak diturunkan oleh Allah, dan ini meliputi mana-mana agama yang tidak diturunkan oleh Allah. Sama ada Hindu, Budha, Confucious, 
Sintoisme ataupun yang lain. Sedangkan batasan: "Kepada baginda Nabi Muhammad saw." juga membatasi agama yang lain, selain agama yang diturunkan kepada Nabi Muhammad saw. Sama ada Nasrani, Yahudi, atau agama-agama Nabi dan Rasul sebelum Nabi saw. Adapun batasan: "Yang mengatur hubungan manusia dengan Al-Khaliq, dengan dirinya dan dengan manusia sesamanya." berarti mencakup seluruh urusan, dunia akhirat, dan yang berkenaan dengan dosa, pahala, surga, neraka, ataupun aqidah, ibadah, ekonomi, sosial, politik, budaya, pendidikan dan sebagainya.

Lebih lanjut Sofyan H. Abdullah menyebutkan secara empirik, kita boleh membuktikan kemampuan Islam sebagai ajaran politik dan spiritual, dengan melihat elemen yang dimiliki oleh Islam, yaitu konsep (fikrah) dan metodologi (thariqah). Konsep ini mencakup: (1) Aqidah Islam, yaitu keimanan kepada Allah, Malaikat, Rasul, Kitab, Hari kiamat dan Qadha'Qadar; (2) Pemecahan masalah kehidupan manusia, yaitu hukum-hukum syara' yang berkenaan dengan penyelesaian semua masalah manusia, yang berkenaan dengan masalah manusia dengan Allah, yaitu ibadah, ataupun masalah manusia dengan sesama manusia, yaitu ekonomi, sosial, politik, pendidikan, penghukuman, dan sebagainya, serta masalah manusia dengan dirinya sendiri, yaitu masalah makanan, pakaian dan akhlaq.

Gus dur menjelaskan agama berfungsi sebagai inspirasi dalam segala kehidupan bernegara dan berbangsa. Kalau toh sering terjadi radikalisme dalam kepemelukan agama, hal itu disebabkan oleh orang-orangnya. "bukan agamanya yang salah," katanya. Namun demikian, tidak berarti agamawan menjadi buta politik. "Justru dia harus mengembangkan pengetahuannya dalam soal politik, agar bisa menjalankan tradisi demokrasi, “ kata Gus Dur (Kompas, 4 Oktober 2006).

Karen Armstrong memahami, setiap agama memiliki naluri, kaidah, atau norma kekerasan. Penganut Protestan di Amerika dan Eropa memimpikan perang pamungkas antara Tuhan melawan setan. Aksentuasi 
dari agresivitas agama membentuk dalam gerakan fundamentalis yang positif maupun negatif. Fundamental dalam pengertian positif sama halnya modernisasi, rasionalisasi spritualitas terhadap teologi agama. Dalam pengertian negatif, fundamentalisme sebagai gerakan ideologi, politik dan kekerasan (Mukhijab, 2006).

Agama di era modernitas ini bisa dibilang telah kehilangan ruhnya. Masyarakat modern lebih menonjolkan sisi rasionalitas dalam mencari kebenaran ketimbang percaya begitu saja pada mitos. Namun sesungguhnya mereka tetap beriman. Hal ini senada dengan pernyataan Paull Tillich yang menyebutkan bahwa, setiap orang memiliki keimanan, karena setiap orang memiliki suatu "urusan terdalam" (ultimate concern), walaupun mereka tidak menyadarinya

\section{Kaitan Agama dengan Ideologi serta Perkembangannya}

Agama dan ideologi adalah dua hal yang menarik untuk diteliti dan dikaji. Kedua-duanya memberikan janji atau tujuan ideal yang diinginkan oleh umat manusia. Agama dan ideologi memberikan gambaran yang lengkap dan utuh terhadap "sesuatu yang-ideal” yang hendak dicapai manusia demi kebahagiaannya. Didalamnya diatur bagaimana tata cara mencapai "yang-ideal", apa yang boleh dan tidak boleh dilakukan dalam bentuknya yang kongkrit atau nyata meski harus di perjuangkan "keberadaannya". Agama dan ideologi sendiri memberikan kepuasan batin, keteguhan yang melahirkan keyakinan bagi penganutnya.

Agama dan ideologi merupakan dua sisi mata uang yang saling berkait. Ideologi bisa disebut agama karena bisa memberikan jalan menuju “yang-ideal” bagi para penganutnya. Begitu juga sebaliknya, agama bukan saja sebagai proses spiritual semata tetapi juga memberikan gambaran "yang-ideal" dan mengatur kehidupan sosial, politik, maupun, budaya.

Untuk memberikan gambaran kaitan agama dengan ideologi, Althuser menyebutkan ideologi sebenarnya bisa dijumpai dalam praktek 
kehidupan sehari-hari dan bukan hanya dalam ide-ide tertentu tentang kehidupan sehari-hari. Baginya, aktivitas-aktivitas ritual, upacara, adat, dan kebiasaan tertentu yang lazim kita lakukan dalam kehidupan sehari-hari nyata-nyata memproduksi akibat-akibat yang mengikat dan melekatkan kita pada suatu tatanan sosial yang mapan, sebuah tatanan yang ditandai oleh adanya kesenjangan status dan gap kekuasaan yang menonjol antara yang Pusat dan yang Periperal, Yang Maha dan yang hamba. Perayaanperayaan agama adalah contoh dari praktek ideologis yang menawarkan pelepasan dan penyegaran dari tuntutan-tuntutan tatanan sosial untuk sementara waktu.

Sedikit berbeda dengan pandangan Althusser, Mohammed Arkoun menyebutkan bahwa, agama dan ideologi mempunyai fungsi umum yang sama; tapi keduanya memakai perangkat yang berbeda dan membuka jalan yang juga berbeda. Keduanya membuat tatanan imajiner dan tatanan nyata masyarakat; keduanya menimbulkan harapan, baik dalam skala individual dan kelompok akan datangnya suatu tatanan yang sempurna dan memberikan dukungan imajiner pada tatanan etis dan politis. Tapi jika agama merujuk pada sesuatu yang sifatnya transenden dan memperkuat momentum mistik menuju yang absolut, maka ideologi mengarah pada satu bentuk tatanan praktis dan terbatas yang diidealkan oleh satu kelompok saja (Arkoun 1993, 48).

Persoalan agama dan ideologi di abad ini adalah pembantaian besar-besaran/genocide. Genocide ini mengakibatkan jutaan nyawa manusia melayang dan barangkali menjadi sia-sia di dalam sejarah peradaban manusia. Ia seolah musnah ditelan bumi, dan atas dasar agama, dan ideologi mereka seolah bebas membunuh manusia lainnya yang belum tentu berdosa. Tentu kita akan bertanya apakah ini subtansi dari ideologi yang mengkerucut dalam tindakan barbar dan amoral.

Hampir bisa dikatakan abad kedua puluh adalah "abad pertarungan ideologi”. Perbedaan ideologi mengakibatkan pembagian Barat-Timur, 
yang mencapai puncaknya pada massa perang dingin, ketika istilah "Marxis" dan Kapitalis" tampakanya hampir menentukan "keburukan" orangorang yang berdiri di sisi lain. Di alam moral, berbagai fundamentalisme keagamaan yang tiba-tiba muncul di seluruh dunia menggambarkan contoh terbaik tentang bahaya ideologi daripada contoh-contoh tunggal lainnya. Setelah kehancuran komunisme soviet pada tahun 1990-an kekuatan fundamentalisme islam kembali menguat. Hal ini membuat ketakuatan/ phobia bagi para penganut kapitalisme yang diwakili oleh amerika. Amerika dalam kebijakan luar negerinya kemudian tampil menjadi pelopor dalam memerangi kekuatan islam dengan mengangkat isu "terorisme". Perang melawan terorisme yang dikomandani Amerika kemungkinannya adalah untuk meminimalisir menguatnya atau bangkitnya islam dalam percaturan global.

Konflik antar agama dan konflik ideologi dalam dasawarsa terakhir dipengaruhi beberapa hal. Penulis sendiri berpendapat bahwa ada dua akar penyebab dari terjadinya konflik di abad modernitas ini. Konflik ini berakar pada: pertama, karena konflik ekonomi yakni penguasaan aset ekonomi yang hanya dimiliki oleh segelintir orang yang memilki modal/ kapital. Kedua, karena terancamnya eksistensi identitas kelompok, etnis, agama, Negara dan juga ideologi. Konflik tersebut lebih disebabkan karena globalisasi yang berkeinginan/memaksakan diri sebagai tatanan tunggal di muka bumi. Globalisasi tidak memandang dan mengenal batas-batas Negara, agama, dan ideology, globalisasi merupakan proyek besar neoliberal yang memaksakan tatanannya atas tatanan dan sistem lainnya.

Tidak sedikit pemikir ilmu sosial yang menganggap bahwa ideologi telah mati dan pertarungan ideologi dimenangkan oleh kapitalisme global. Fukuyama misalnya, ia menyebutkan bahwa apa yang kita saksikan ini bukanlah akhir perang dingin, atau sejarah pasca perang tetapi akhir dari sejarah, yakni titik akhir dari evolusi ideologi umat manusia dan universalisasi demokrasi liberal barat sebagi bentuk final pemerintahan 
umat manusia (Fukuyama, 2004).

Sementara itu Daniel Bell, sosiolog Amerika, pernah berusaha keras untuk membunuh ideologi. Era saat ini adalah era akhir zaman ideologi dan memasuki tahap akhir sejarah yang akan membebaskan manusia dari frustasi dan mewujudkan aspirasi untuk mendapatkan standar kehidupan yang layak (Fukuyama, 2004).

Kematian ideologi ini dilatar belakangi dari asumsi bahwa kapitalisme yang diwakili Amerika telah menang melawan USSR yang berideologi komunisme. Kapitalisme telah menunjukkan hegemoninya atas ideologi lainnya, terutama komunisme. Kehancuran komunisme sendiri ditandai dengan dihancurkan tembok berlin yang memisahkan Jerman Barat dan Jerman Timur pada tahun 1990-an. USSR sendiri telah terpecah belah kedalam Negara-negara bagian dan lebih condong terhadap Negara kapitalisme yang diwakili Amerika.

Namun, bagi penulis ideologi hingga kini masih menarik untuk diperdebatkan dan masih relevan untuk didiskusikan. Kebangkitan islam pasca jatuhnya komunisme menunjukkan bagaimana ideologi mempunyai peranan yang kuat dalam tradisi gerakan islam. Ideologi menjadi semacam senjata yang mampu mengikat umat islam dalam menjalin solidaritas yang terejewantahkan melalui gerakan keagamaan dan kultural. 


\section{Referensi}

Adams, Iam. 2004. Ideology Politik Mutakhir; Konsep, Ragam, Kritik, dan Masa Depannya. Qalam, Yogyakarta. Cet Pertama.

Arkoun, Mohammed. 1993. "Pemikiran Tentang Wahyu, Dari Ahl al-Kitab sampai Masyarakat Kitab. Ulumul Qur’an, No. 2/Vol.IV. hal.48

Barker, Chris. 2009. Cultural Studies. Kreasi Wacana. Yogyakarta. Cet. Keenam

Budiman, Hikmat.1997. Pembunuhan yang Selalu Gagal, Modernisme dan Rasionalitas Menurut Daniel Bell. Pustaka Pelajar. Yogyakarta

Fukuyama, Francis. 2004. The end of History and The Last Man. Qalam. Yogyakarta. Cet. Keempat

Mukhijab. Karen Armstrong dan Norma Agresivitas Agama. Pikiran Rakyat. Senin, 25 Oktober 2006

Palmquis, Stephen. 2002. Pohon Filsafat. Pustaka Pelajar. Yogyakarta. Cet. Pertama

Simon, Roger. 2000. Gagasan-gagasan Politik Gramsci. Yogyakarta. Pustaka Pelajar. Cet. Kedua.

Storey, John. 2004. Teori Budaya dan Budaya Pop: Memetakan Lanskap Konseptual Cultural Studies. Qalam. Yogyakarta

Sugiharto, I. Bambang.1996. Posmodernisme. Tantangan Bagi Filsafat. Kanisius. Yogyakarta. Cet. Kelima.

Microsoft Encarta Encyclopedia. 2003

Kompas, Selasa, 4 Oktober 2006 